NOTICE: This is the author's version of a work that was accepted for publication in Electoral Studies. Changes resulting from the publishing process, such as peer review, editing, corrections, structural formatting, and other quality control mechanisms may not be reflected in this document. Changes may have been made to this work since it was submitted for publication. A definitive version was subsequently published in Electoral Studies, Vol. 23 (2004). doi: 10.1016/S02613794(02)00055-0 
Charnock, David and Ellis, Peter. (2004). Postmaterialism and Postmodernization in Australian electoral politics, Electoral Studies, 23(1):45-72.

\title{
Postmaterialism and Postmodernization in Australian electoral politics
}

\section{David Charnock and Peter Ellis}

\author{
School of Social Sciences, \\ Curtin University, \\ GPO Box U1987, \\ Perth WA 6845, \\ Australia.
}

\section{Corresponding author: David Charnock}

\section{Email: D.M.Charnock@curtin.edu.au}

\section{Fax: + 61892663166}

Note: Some of the initial work for this article was carried out while the first author was visiting the Department of Sociology, University of North Carolina at Chapel Hill and the Research School of Social Sciences at the Australian National University, Canberra; he would like to thank those institutions for their hospitality. We also thank Kay Fisher and the journal's reviewers for helpful comments on earlier drafts. The work was partly supported by Australian Research Council Large Grant A79938063. 
Charnock, David and Ellis, Peter. (2004). Postmaterialism and Postmodernization in Australian electoral politics, Electoral Studies, 23(1):45-72.

\title{
Postmaterialism and Postmodernization in Australian electoral politics
}

\begin{abstract}
In this paper we explore recent Australian electoral politics using both Inglehart's ideas on postmaterialism and also a broader conception of postmodern attitudes. We begin by demonstrating that the widely-used postmaterialism measure based on Inglehart's fouritem question gives completely counterintuitive results for the most recent significant Australian party, the One Nation Party. This appears to support Warwick's argument that this measure actually reveals pro-democracy propensity. Subsequently, we develop a much broader measure of postmodern attitudes and use this in conjunction with an index of left-right attitudes to explore the positioning of party supporters in the resulting twodimensional space and the practical consequences of this. Among other things, this demonstrates that a single left-right dimension is inadequate to describe the positioning of minor parties in particular, but that it is overall of more significance in predicting vote than is the postmodern dimension.
\end{abstract}

Keywords: Postmaterialism; Postmodernization; Australian electoral politics; One Nation party 
Charnock, David and Ellis, Peter. (2004). Postmaterialism and Postmodernization in Australian electoral politics, Electoral Studies, 23(1):45-72.

\section{Postmaterialism and Postmodernization in Australian electoral politics}

\section{Introduction}

In common with many western democracies, Australian political discourse and voting behaviour is still often described in terms of a single left-right dimension. Sometimes this has been put in the context of a belief that a dichotomous social class division based on economic interests is the key underlying aspect, but as such a simple description has become increasingly untenable more pragmatic considerations have been mentioned. For example, McAllister (1992) argues that it is in the interest of the major parties to keep debate focused on economic issues to avoid the divisiveness of social issues (both amongst their own supporters and society at large). Moreover, if party competition can largely be restricted to a single dimension, this has the additional advantage for the major parties of making it difficult for other parties to establish a niche for themselves among the voting public.

Traditional major party competition has been between the Australian Labor Party (ALP) and the longstanding Liberal-National coalition for over half a century. However, particularly since the mid-1970s, there has been a large increase in the rate of formation

of new parties ${ }^{1}$, of which the most significant are probably the Australian Democrats, the Greens and, most recently, Pauline Hanson’s One Nation Party (ONP). Concomitantly, there have been changes in the extent of voting for major parties (with a total of $96 \%$ voting for the ALP and Liberal-National coalition in the House of Representatives in 1975, down to just below $80 \%$ in 1998). This situation is not, of course, unique to Australia: indeed, in the middle part of the 1990s it was argued (Charnock 1996; McAllister 1997) that the extent of major party dealignment in Australia had been relatively small by international standards and some people would argue that this still remains true.

Nevertheless, the increasing significance of the newer parties has prompted some reexamination of the adequacy of the traditional left-right interpretation of electoral politics, with Jackman (1998) and Weakliem and Western (1999) being two recent 
Charnock, David and Ellis, Peter. (2004). Postmaterialism and Postmodernization in Australian electoral politics, Electoral Studies, 23(1):45-72.

prominent examples. In the broader international context, one of the most influential accounts of factors underlying these kinds of changes has been provided by Ronald Inglehart (1977; 1990; 1997). He argues that value orientations are based on childhood conditions; that those brought up in materially secure conditions are more likely to hold postmaterialist values relating to self-expression and the quality of life (such as freedom, democracy, beauty and the importance of ideas); and that increasing proportions of today’s voters, raised during post-World War II prosperity, have such values.

Most recently (Inglehart 1997), he generalizes beyond postmaterialism to argue that western industrial democracies have in some sense moved beyond the 'modernization' project into a process of 'postmodernization'. Postmodernization is conceived as dependent upon a degree of success in the modernization project and he uses the World Values Survey data to argue that the aggregate values of the 43 nations surveyed can be placed along a sequence of modernization and postmodernization. While terms relating to postmodernism have many different and competing meanings (Gibbins and Reimer 1999), Inglehart uses the term 'postmodernization' to describe an emerging historical phase in which the processes of economic, cultural, and political change shape values and behaviour in coherent and predictable ways: "In the postmodernization phase of development, emphasis shifts from maximizing economic gains to maximizing subjective well-being” (Inglehart 1997: 86). Postmodern values are argued to form a coherent pattern that, in addition to postmaterial values, includes things such as tolerance and permissiveness. Inglehart thus argues that the postmaterialist shift is "only one part of a broader shift toward postmodern values, involving changing orientations towards politics, work, family life, religion, and sexual behaviour” (1997: 132). These values are reflected in the prioritization of a range of issues, such as environmental protection, abortion, ethnic diversity, women's issues, and gay and lesbian emancipation (Inglehart: 1997; 4, 237, 246).

In the political realm, Inglehart argues that the new postmodern political dimension is required to understand the declining priority of the economic concerns central to traditional notions of Left versus Right politics, and the emergence of new political 
Charnock, David and Ellis, Peter. (2004). Postmaterialism and Postmodernization in Australian electoral politics, Electoral Studies, 23(1):45-72.

parties and new issues. Typically, the most extreme postmodern position within each political arena is taken by a party of the libertarian or New Left, while the opposing pole is occupied by a party of the New Right.

The terminology used in this description suggests this dimension is not wholly independent of the traditional Left-Right dimension and Kitschelt (1994; 1995), arguing that the new dimension is better described as libertarian-authoritarian, provides empirical support for the existence of a new axis of party competition in Europe, in which competition is seen as taking place in this two-dimensional space, but generally along a left-libertarian to right-authoritarian diagonal line within that space (also see Hellevik 1993; Knutsen 1995).

In Inglehart's own most recent work, however, although he recognizes that the postmodern dimension is broader than the materialist-postmaterialist distinction on which his earlier work was based, much of his discussion of the relationship between politics and social and cultural change is constructed in the language of postmaterialism. For example, with reference to Germany, he says (Inglehart 1997: 245-6):

"the Republikaner do not call themselves the Anti-Environment Party; nor do the Greens call themselves the Pro-Immigrant Party. But, in fact, their constituencies are disproportionately Materialist and Postmaterialist, respectively; and these parties adopt opposite policies on the relevant issues. The older parties are arrayed on the traditional Left-Right axis, established in an era when political cleavages were dominated by social class conflict... As Kitschelt (1995) has demonstrated, the new politics dimension is not perpendicular to the longestablished Left-Right dimension. Instead, the Greens are closer to the old Left on key issues, while the Republikaner are closer to the Right ...(but) the Postmaterialist Left appeals primarily to a middle-class constituency and is only faintly interested in the classic program of the left. For example, Postmaterialists are not necessarily more favourable to state ownership than are Materialists.” 
Charnock, David and Ellis, Peter. (2004). Postmaterialism and Postmodernization in Australian electoral politics, Electoral Studies, 23(1):45-72.

\section{Australian political context}

How do these ideas apply to Australia? There are many parallels, with the ALP and the Liberal-National coalition having tended to operate along the left-right dimension, although the rural base of the Nationals has created some tensions at times. The Australian Greens are comparable to their European counterparts; the Australian Democrats were founded in the late 1970s and, at least initially, were often described as being a manifestation of a postmaterialist party (though see Marks and Bean 1992 for a fuller discussion of their sources of support).

However, until very recently there has been no counterpart to the anti-immigrant, populist parties that exist in many European countries. Since Australia has encouraged large-scale post-WWII immigration (and readily grants citizenship and voting rights to migrants), this is perhaps not surprising: around 23 per cent of the current population were themselves born overseas (a larger proportion than any other OECD country except Luxembourg and much larger than most European countries), and over 40 per cent of the population were either themselves born overseas or have at least one parent born overseas. However, the racial balance of immigrant arrivals has changed considerably since the mid-1970s, prior to which it was predominantly British and European. Also, Australia has been subject to most of the economic and social transformations that have occurred in Europe and North America, so it should not have been surprising that the most recent significant entrant into the party system is such a populist party.

This is the One Nation Party, which ran candidates federally for the first time in 1998 and obtained almost 10 per cent of the vote in both the House of Representatives and Senate, more than either the Greens or the Australian Democrats. Characterizations of the voting support for ONP have drawn on both economic insecurity and attitudes towards race and immigration (e.g. Abbott et al 1998), although the latter seem to have been more significant than the former at the 1998 election (Charnock 1999; Gibson et al 2001; Goot and Watson 2001; McAllister and Bean 2000). Denemark and Bowler (2002: 53) suggest the concerns with national identity of voters for ONP and New Zealand First, while different to the non-material concerns central to Inglehart's ideas, "must be seen as 
Charnock, David and Ellis, Peter. (2004). Postmaterialism and Postmodernization in Australian electoral politics, Electoral Studies, 23(1):45-72.

representing a qualitatively different attitudinal dimension from the sorts of pocketbook issues over which the centrist parties primarily compete”. Further evidence of the importance of such attitudes in Australia is provided by the analysis in Charnock (2001), which demonstrates the impact of national identity on voting at the 1999 Republic referendum and its relationship with partisanship.

Though absent from the postmaterialism measure, the rise of expressions of xenophobia and xenophobic parties is quite consistent with Inglehart's account of postmodernization. In fact, he argues that clashes over tolerance issues form an important aspect of the shift towards postmodernization, as those holding materialist values react against the rising influence of the postmodern value of ethnic tolerance, to a large extent due to a sense of insecurity.

Based upon similar diagrams for France and Germany in Inglehart (1997), it therefore seems that we are justified in proposing a schema of the nature of Figure 1 for Australian politics, with ONP at one end of a postmodern attitudes dimension and the Australian Democrats or Greens at the other.

Figure 1

Idealized Inglehart-style diagram possibly representing Australian electorate

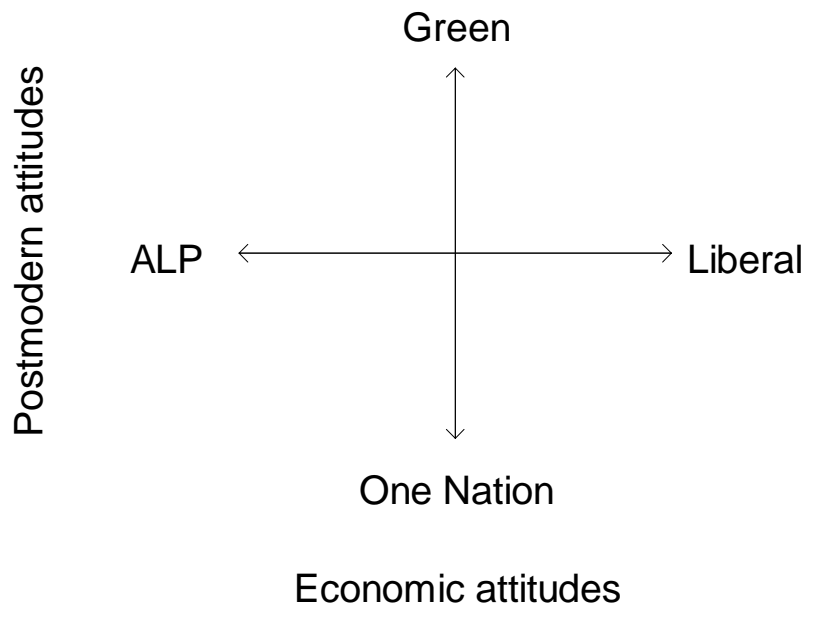


Charnock, David and Ellis, Peter. (2004). Postmaterialism and Postmodernization in Australian electoral politics, Electoral Studies, 23(1):45-72.

As mentioned earlier, the recent work by Jackman (1998) and Weakliem and Western (1999) has begun to offer some understanding of dimensionality in Australian political choice. Weakliem and Western (1999) examine the relationship between occupational class and House of Representatives vote as reported in Gallup polls pooled over the period 1943-96 and suggest a traditional ALP-DLP-Liberal (manual-business) dimension can be contrasted with a new dimension with the Greens and Democrats at one extension, associated with non manual workers and professionals. However, this approach can only pick up dimensionality based on occupation, and hence cannot directly address the values at the heart of the postmodernization thesis; further, it is hampered by not having a logical candidate for the other end of the postmodern scale from the Greens.

Jackman (1998) examines dimensionality of attitudes based on the 1996 Australian Election Study and considers a two-dimensional attitude space, with attitudes to unions representing a traditional left-right dimension and attitudes to race representing a cross cutting dimension. He finds attitudes on these dimensions are correlated: anti-union attitudes are associated with racially conservative attitudes, although this is more so with candidates than the electorate, who see no contradiction in "describing themselves as leftof-centre but still offering relatively conservative opinions on government assistance for Aborigines or levels of immigration.” (Jackman 1998: 182)

However, since he was mainly concerned with attitudes to race, in particular the relationship between elite and electorate opinion and the temptation to 'play the race card', he does not directly address the question of whether the emergence of the race dimension indicates a broader realignment of political discourse along the lines suggested by Figure 1.

In the Australian context, empirical research on the relationship between postmodernism and voting has been largely confined to discussion of the role of postmaterialism, with several authors having looked directly at the question of the emergence of postmaterialism in Australian politics. In one of the earliest significant analyses, Gow (1990: 60) uses data from the 1990 Australian Election Study (McAllister et al 1990) to argue that "by and large, there is no regular pattern of differences between the two polar 
Charnock, David and Ellis, Peter. (2004). Postmaterialism and Postmodernization in Australian electoral politics, Electoral Studies, 23(1):45-72.

groups [materialists and postmaterialists]", although some of the data analysis he presents does show that postmaterialists were much more likely to vote for the Australian Democrats than were materialists.

Blount (1998) criticises aspects of the analytical approach adopted by Gow and argues that there is actually a postmaterialist effect, which manifests itself in the Senate vote for minor parties. However, Blount himself uses questionable statistical techniques, relying upon an arbitrary continuous scale for vote as response, thus implicitly assuming a one dimensional continuum in Australian politics, which should instead be one of the key aspects to be tested in any consideration of the rise of postmaterialism and postmodern politics. A better method is multinomial logistic regression, as used by Charnock (1999) and Denemark and Bowler (2002), and later in this paper.

Western and Tranter (2001) also use multinomial logistic regression to examine the link between postmaterialism, economic evaluations and voting behaviour. They confirm that "Australian political parties cannot easily be arrayed on a single unidimensional continuum" (page 456) and find that postmaterialists vote disproportionately for both the Australian Democrats and Greens in both the House and Senate, at the expense of the Liberal, Labor and National parties.

In what follows, we will relate our work to some of the previous Australian research mentioned above by beginning with an examination of the relationships between voting and measures of postmaterialism, but will later extend our analysis to include a broader consideration of postmodern politics. To do so, it will be necessary to examine a range of attitudes held by voters, and consider voting patterns for minor as well as major parties. Rather than focusing on 'economic voting' and economic evaluations (as do Blount, Gow, and Western and Tranter), we will follow the Inglehart and Kitschelt approach which draws on Left-Right economic ideology as the basis for the traditional political dimension. This will help us to get a more nuanced assessment of differences between the minor parties in particular. 
Charnock, David and Ellis, Peter. (2004). Postmaterialism and Postmodernization in Australian electoral politics, Electoral Studies, 23(1):45-72.

\section{Data and measures}

Since the 1998 Federal election was the first in which ONP ran candidates, analyzing data from that election provides an excellent opportunity to test the idealized schema outlined in Figure 1. Consequently, our primary source of data is the 1998 Australian Election Study (Bean et al. 1999)².

A question of potential importance is whether to study vote in the House of Representatives or in the Senate, or even possibly party identification. We follow Blount (1998) in looking to the Senate to exhibit evidence of the postmodernization of politics. In part, this is because the voting system in the Senate (multi-member, with a quotapreferential system) is more 'minor party-friendly' because of its more proportional outcomes, but a further reason for examining Senate vote is the greater consistency in choice offered to voters. In the House, voters in each of the electoral divisions (of which there are usually just under 150) face differing choices, with (apart from the possible importance of constituency-specific issues and personalities) not all parties offering candidates in every contest. In particular, it becomes impossible to separately analyse voters for the National and Liberal parties: in view of the way in which One Nation apparently obtained much of its support in previously National areas, this is an important deficiency ${ }^{3}$.

\section{Left-Right economic ideology}

Inglehart's argument (and, of course, many other authors') suggests the creation of a traditional left-right cleavage around issues such as state ownership. With the questions available in the AES98, and in view of the degree of attitude instability shown by Johnston and Pattie (2000), we decided to form an index based both on individual selfplacement on a left-right scale and also on responses to some relevant individual questions, specifically:
D13SOCEC
Australia better off with a socialist economy
D13EQUAL
Income and wealth should be redistributed 
Charnock, David and Ellis, Peter. (2004). Postmaterialism and Postmodernization in Australian electoral politics, Electoral Studies, 23(1):45-72.
D13TUPOW
Trade unions have too much power
D13STRCT
Stricter laws to regulate trade unions
E1
Choice between taxes and social services
B10OWN
Own left-right position

The index was scaled to have a range of values from 0 to 1 , with 0 indicating extreme left-wing and 1 indicating extreme right-wing.

\section{Postmaterialism}

Arguments over the validity, reliability, theoretical content and probable causality of postmaterialism abound, and measuring and interpreting postmaterialism are topics of some controversy in the political science and other literature (for example, see Bean and Papadakis 1994, and the recent debate in the American Political Science Review (Clarke et al 1999; Davis and Davenport 1999; Inglehart and Abramson 1999)). There are two standard measures (see the appendix for details). The first (which was the earliest one used) is based on a single ranking exercise, with four national aims (two materialist and two postmaterialist) from which to select. The second is based on three such questions, making a total battery of twelve items. The four-item battery results in classifications of survey respondents as “materialist”, "postmaterialist”, or "mixed”. The standard way of aggregating this figure by group (party, country, etc) is to cite the difference between the percentage of postmaterialists and the percentage of materialists (e.g. Inglehart 1997: 136). As outlined in the appendix, the twelve-item battery results in a score ranging from zero (completely materialist) to five (completely postmaterialist) (Inglehart 1997: 130).

Much of the postmaterialism measurement controversy stems from the choice of rival aims that are offered in the four-item battery. These are:

- maintaining order in the nation;

- giving people more say in important government decisions;

- fighting rising prices;

- protecting freedom of speech. 
Charnock, David and Ellis, Peter. (2004). Postmaterialism and Postmodernization in Australian electoral politics, Electoral Studies, 23(1):45-72.

Warwick (1998) argues that the four-item measure is actually revealing a 'prodemocracy' orientation. Several critics have also argued that postmaterialism on this measure reflects the economic circumstances that obtain at the time of the interview, rather than economic stability at the time of upbringing (as Inglehart proposes). Clarke et al (1999) show how, within the measure based on the four items, "substituting an unemployment statement for the standard inflation statement in the battery has major consequences for the classification of respondents as materialist or postmaterialist" (page 637) and that the four-item measure is strongly dependent on economic conditions. They make the cogent criticism that "When inflation is not a salient economic problem, respondents eschew the rising prices item but are forced by the format to choose one of the remaining three, none of which deals with other economic concerns they may have. Respondents who do not select the prices item have a zero probability of being classified as materialist.” (page 638)

In view of these difficulties with the four-item scale, it is somewhat unfortunate that only the four-item battery was asked in the 1998 AES. It does, however, give us the opportunity to contribute to the debate about the merits of the measure; as we will demonstrate, it gives some very surprising results about ONP voters, thus reinforcing some of the earlier criticisms of it.

\section{Postmodernism}

In attempting to explain an apparently anomalous high probability of being postmaterialist for ONP supporters at the 1998 House of Representatives election, Denemark and Bowler (2002) suggest that national identity is still a non-materialist concern, although it is not among Inglehart's materialist-postmaterialist items. As noted above, while Inglehart argues that the postmodern dimension of politics is strongly associated with the postmaterialism-materialism divide, he does also recognise that a broader consideration of postmodern politics will sometimes be necessary. The problematic nature of the four-item postmaterialism measure available in AES98 makes it even more 
Charnock, David and Ellis, Peter. (2004). Postmaterialism and Postmodernization in Australian electoral politics, Electoral Studies, 23(1):45-72.

important that we operationalize postmodernism on a more sophisticated basis than postmaterialism alone.

One way to do this is directly in terms of key aspects involved in Inglehart's suggested new, non-class based dimension. Accordingly, drawing on the data available in AES98 and giving specific attention to the importance of Aboriginal issues in the Australian context, we created 5 indices (see below) to measure individuals' positions on cultural permissiveness, xenophobia, rights for minority or oppressed groups and environmental priorities $^{4}$. As with the left-right economic ideology index, each index was scaled to range from 0 to 1 , with 1 indicating the most postmodern stance.

\section{Cultural permissiveness (PERMIS)}

E2NUDSEX Nudity \& sex in films and magazines

E3 Allow euthanasia - patient has incurable disease

E4 Allow euthanasia - patient tired of living

E6MARIJ Decriminalise smoking of marijuana

E17P5 Importance of traditional ideas of right and wrong

\section{Attitudes to immigrants (IMMIG)}

F6

Number of immigrants increased

F7P1 Immigrants increase crime

F7P3 Immigrants take jobs from Australian born

F5P11 Foreigners shouldn’t buy land

\section{Environmentalism (ENV)}

E14PRESN Nature one of the most precious things in life

E14SPEND Increase spending to protect environment

E14POLLT Stronger measures against pollution

E15ENVIR Approve of environmental groups 
Charnock, David and Ellis, Peter. (2004). Postmaterialism and Postmodernization in Australian electoral politics, Electoral Studies, 23(1):45-72.

\title{
Attitudes towards Aborigines (AB)
}

E2ABLAND Aboriginal land rights

E2ABOR Government help for Aborigines

G14P7 Special cultural protection for Aborigines

G14P8 Recognise aspirations of Aborigines

G14P9 Aborigines' right to self-government

\section{Attitudes towards equal opportunities (EEO)}

E2EQUOP Equal opportunities for women

E6OPP Increase business opportunities for women

E17P2 Importance of EEO in hiring and promotion

E17P3 Importance of special effort to protect minorities

E17P4 Importance of equality between men and women

\begin{abstract}
Almost all of these items are measures of attitudes ('an organization of several beliefs about a specific object or situation' (Rokeach 1973: 181)); the implication of Inglehart's ideas is that attitudes towards these kind of issues actually flow from a fairly coherent underlying value orientation and so, if Inglehart's thesis is correct, these attitudes should to a reasonable degree be able to be summarised in a single dimension ${ }^{5}$. Accordingly, in addition to looking at the five indices separately, we can also calculate a single “postmodern attitudes” index, based on all 23 questions. It then becomes an empirical question as to whether using the five separate indices adds anything of significance to our understanding of voting behaviour, when compared to using the single combined postmodern attitudes index ${ }^{6}$.
\end{abstract}

\section{Results and Discussion}

We begin with an examination of the relationship in 1998 between postmaterialism (using the four-item battery included in the AES) and left-right attitudes (see Figure 2). 
Charnock, David and Ellis, Peter. (2004). Postmaterialism and Postmodernization in Australian electoral politics, Electoral Studies, 23(1):45-72.

Figure 2

Postmaterialism and Left-Right economic positions of Senate voters 1998

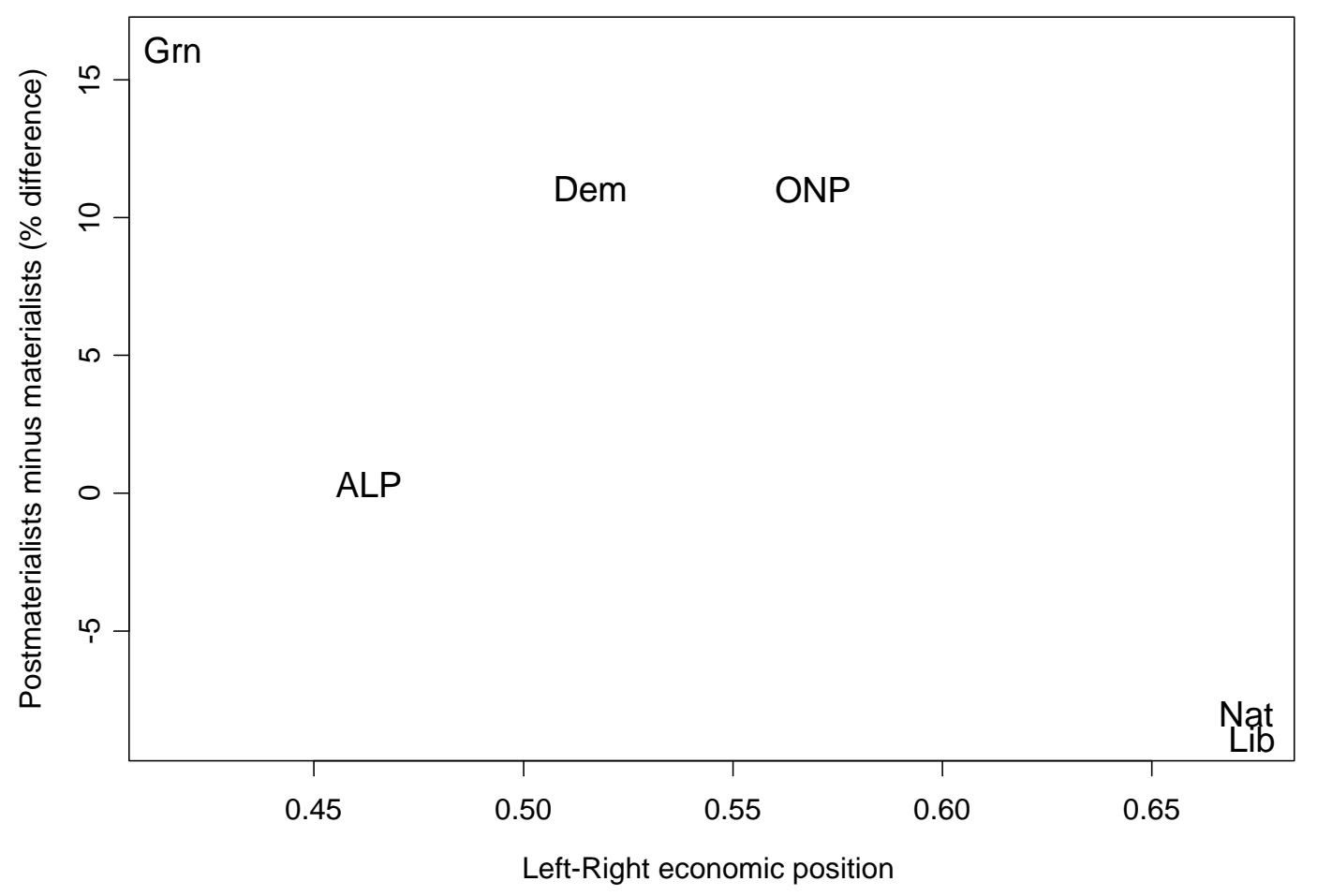

This apparently shows Inglehart's thesis to fail quite badly in at least one respect, when he argues (Inglehart 1997: 245, 248) that the top of the postmodernist politics dimension is a postmaterialist pole, with the other end disproportionately made up of materialists. In fact, Figure 2 shows ONP voters sharing with the other minor parties a high proportion of postmaterialists minus materialists, at least compared to the major parties. On this measure, ONP is as postmaterialist as the Australian Democrats, a very counterintuitive finding. As well, the Greens are well to the left on traditional left-wing attitudes (in contrast to Inglehart's (1997: 246) claim that "the Postmaterialist Left appeals primarily to a middle-class constituency and is only faintly interested in the classic program of the Left”). 
Charnock, David and Ellis, Peter. (2004). Postmaterialism and Postmodernization in Australian electoral politics, Electoral Studies, 23(1):45-72.

In view of other research into the nature of ONP support, this clearly demonstrates the inadequacy of the four-item measure. The inadequacy is probably best interpreted in the light of Warwick’s (1998: 603) finding that the “...index registers support for democratic principles in particular, and not simply a more general postmaterialism.” In the Australian context, it is not a surprise that ONP voters, often characterised as anti-elite, feeling left out of the Australian political and economic landscape, and opponents of "political correctness" as a form of implicit censorship of "ordinary Australians", are inclined to believe that "giving people more say in important government decisions" and "protecting freedom of speech" are important aims for Australia.

These measurement difficulties mean that a better test of the postmodernization thesis is one based on the postmodern attitudes index described above, constructed from the responses to all 23 questions on issues such as the environment, immigration, Aborigines and EEO. Figure 3 relates the postmodern attitudes of Senate voters (as measured on this scale) to their Left-Right economic position. 
Charnock, David and Ellis, Peter. (2004). Postmaterialism and Postmodernization in Australian electoral politics, Electoral Studies, 23(1):45-72.

\section{Figure 3}

\section{Postmodern political and Left-Right economic positions of Senate voters 1998}

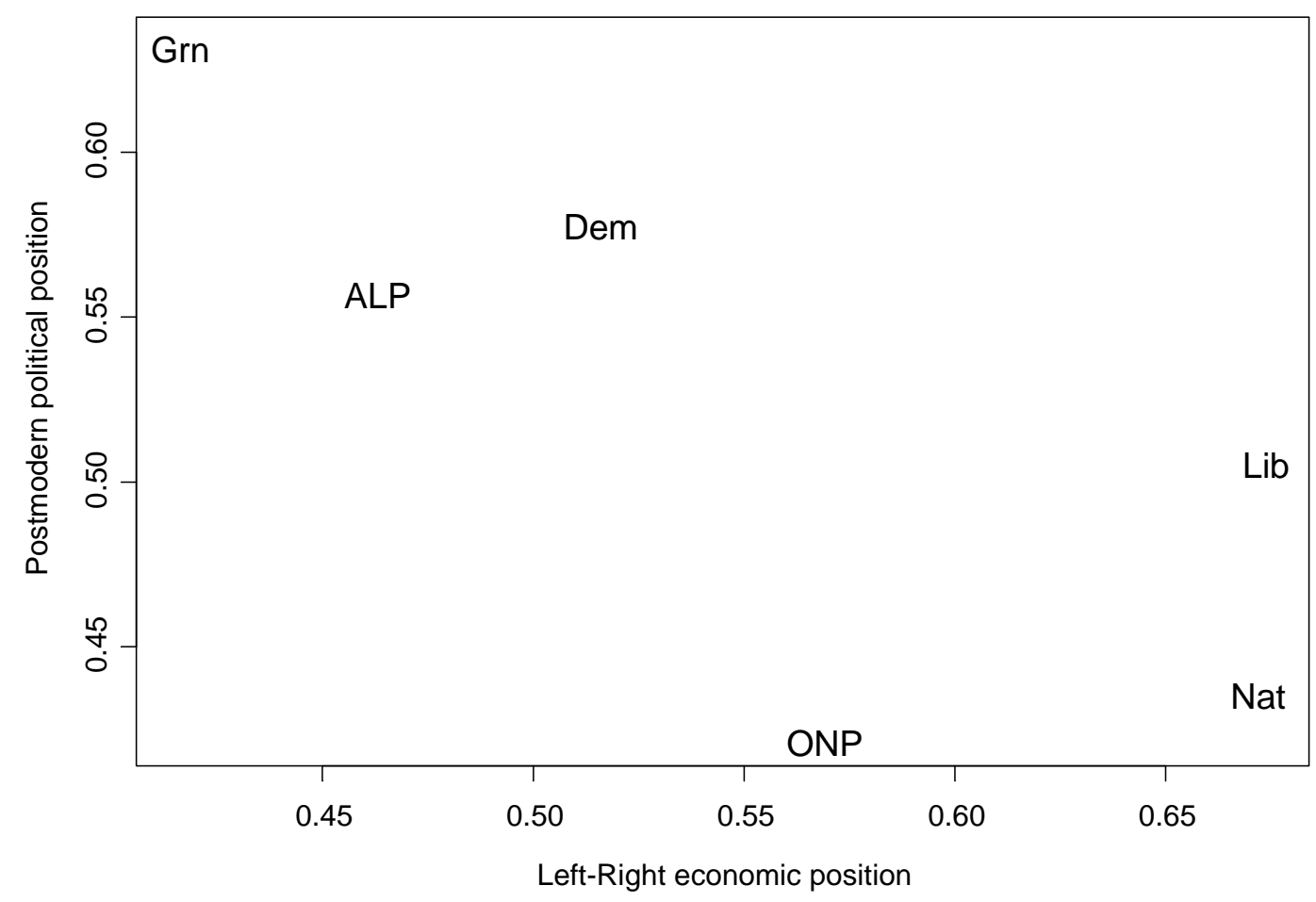

The position of ONP here is much more in accordance with perceptions of the party and previous research about its supporters than that indicated in Figure 2, thus suggesting that this index is considerably more appropriate than ones derived from the four-item materialism-postmaterialism battery. Comparing Figure 3 with the idealized twodimensional space we started with in Figure 1, we can see a general congruence. The main discrepancy is the strong traditional left-wing position of Greens voters in the Senate. The pattern does, in fact, appear rather closer to Kitschelt's (1994) findings, with a diagonal axis of party competition. 
Charnock, David and Ellis, Peter. (2004). Postmaterialism and Postmodernization in Australian electoral politics, Electoral Studies, 23(1):45-72.

ONP can be seen to occupy a pole of a postmodern politics dimension with the Greens at the opposing extreme and the other parties at predictable positions in between. The distinction between Liberal and National voters is on postmodern, not Left-Right issues. Democrats supporters occupy a middle ground on economic issues but are very slightly more postmodern than the ALP. Greens voters are both the most postmodern and also the most left-wing party, and the Greens fit rather better into the mould of a left-libertarian party than Inglehart's picture of postmaterialists who have little interest in classic left redistributive agendas.

At least visually, then, it does appear from Figure 3 that picturing parties’ positions in a two-dimensional space, incorporating a postmodern attitudes dimension in addition to a more traditional left-right economic dimension, helps in understanding recent Australian electoral politics. The relative positions of the parties on the two dimensions are not the same, with ONP being the least postmodern but fairly close to the centre on left-right issues (showing that the quite common description of ONP as an 'extreme right' party is inaccurate and misleading). However, the division between ALP and Liberal voters is very largely defined in terms of left-right economic positions.

\section{Individual voting models}

We now proceed to estimate some statistical models relating individual voting to the various indices we have mentioned, both in order to give a more precise account to match the visual impression already discussed, and also to investigate the extent to which using the five separate indices in place of the single postmodern attitudes index gives a finergrained picture of what differentiates voters for the various parties. These models will give us a relatively simple way of describing the apparent impact of postmodernization of attitudes on the Australian party system.

In addition to a null model (to obtain a baseline for assessing the other models), we present complete details of four models: one with only the left-right economic index (model A1), one with only the single postmodern attitudes index (model A2), one with both of these two (model B), and one with the left-right economic index and all five of 
Charnock, David and Ellis, Peter. (2004). Postmaterialism and Postmodernization in Australian electoral politics, Electoral Studies, 23(1):45-72.

our separate indices for the different components of postmodern attitudes (model C). Examination of these models allows us to assess both the relative importance of left-right and postmodern attitudes, and also whether the five separate indices add much over the single postmodern index.

We also present summary results for two other models, one with the postmaterialism measure only and another with the left-right economic index together with the aboriginal and environmental attitudes indices. The first of these allows us to compare the association with voting of the narrower postmaterialism measure with that of our broader index of postmodern attitudes; the second allows us to consider whether the explanation in terms of postmodern attitudes in general is superior to an alternative one that relies on racial and environmental attitudes only and that might be suggested by Jackman's (1998) work $^{7}$.

We use multinomial logistic modeling (see, for example, Long 1997). In this form of modelling, one category of the dependent variable is set as a reference category. As above, we study Senate vote, and we make Liberal vote the reference category. Studying Senate vote allows us to meaningfully separate Liberal from National voters, and thus examine differences between the two coalition partners, something that is not often done in Australian voting analyses.

Tables 1 to 5 show the results of our main models (null and models A1, A2, B and C as outlined above). Unbracketed numbers are the estimates of the size of the coefficient compared to Liberal voters; bracketed numbers are the corresponding standard errors. On standard interpretation and presentation of results, an estimate of a coefficient that is roughly twice the size of its standard error can be described as statistically significantly different from zero (i.e. significant evidence of a difference from the Liberals on this issue).

A negative coefficient for the 'left-right economic' variable indicates Left-wing voters are more likely to vote for that party than for the Liberals; a negative coefficient for the various postmodern indices indicates postmodern voters are less likely to vote for that 
Charnock, David and Ellis, Peter. (2004). Postmaterialism and Postmodernization in Australian electoral politics, Electoral Studies, 23(1):45-72.

party than for the Liberals. Coefficients should be interpreted as showing the association between the variable and vote once the other variables in that particular model have been controlled for. Thus, looking at the second row of Table 4 (Model B), we see that, having controlled for left-right economic position (on which differences between the Liberal and National coalition partners are statistically nonsignificant), "postmodernists" are less likely to vote for the Nationals than for the Liberals.

Table 1: Null Model for 1998 Senate vote

\begin{tabular}{|l|r|}
\hline & $\begin{array}{r}\text { Intercept } \\
\text { Est. (s.e.) }\end{array}$ \\
\hline ALP & $0.07(0.06)$ \\
\hline Nat & $-2.16(0.13)$ \\
\hline Dem & $-0.81(0.08)$ \\
\hline Grn & $-2.59(0.16)$ \\
\hline ONP & $-1.51(0.10)$ \\
\hline AIC: $4838.4 \quad$ n: 1679 & $36.6 \%$ correctly predicted
\end{tabular}

Table 2: Model A1

\begin{tabular}{|l|r|r|}
\hline & $\begin{array}{r}\text { Intercept } \\
\text { Est. (s.e.) }\end{array}$ & $\begin{array}{r}\text { Left -Right Economic } \\
\text { Est. (s.e.) }\end{array}$ \\
\hline ALP & $5.52(0.31)$ & $-9.54(0.53)$ \\
\hline Nat & $-2.16(0.63)$ & $0.00(0.92)$ \\
\hline Dem & $3.57(0.34)$ & $-7.34(0.58)$ \\
\hline Grn & $3.63(0.51)$ & $-11.29(1.05)$ \\
\hline ONP & $1.56(0.43)$ & $-4.93(0.70)$ \\
\hline \multicolumn{2}{|c|}{ AIC: $4276.4 \quad \mathrm{n}: 1679$} & $54.0 \%$ correctly predicted
\end{tabular}

Table 3: Model A2

\begin{tabular}{|c|c|c|}
\hline & $\begin{array}{l}\text { Intercept } \\
\text { Est. (s.e.) }\end{array}$ & $\begin{array}{l}\text { Postmodernism } \\
\text { Est. (s.e.) }\end{array}$ \\
\hline ALP & $-2.28(0.30)$ & $4.42(0.56)$ \\
\hline Nat & $0.89(0.59)$ & $-6.47(1.29)$ \\
\hline Dem & $-4.05(0.4 \odot)$ & $5.99(0.71)$ \\
\hline Grn & $-8.10(0.85)$ & $9.74(1.35)$ \\
\hline ONP & $2.10(0.46)$ & $-7.78(1.01)$ \\
\hline
\end{tabular}


Charnock, David and Ellis, Peter. (2004). Postmaterialism and Postmodernization in Australian electoral politics, Electoral Studies, 23(1):45-72.

Table 4: Model B

\begin{tabular}{|c|c|c|c|}
\hline & $\begin{array}{l}\text { Intercept } \\
\text { Est. (s.e.) }\end{array}$ & $\begin{array}{l}\text { Left-Right } \\
\text { Est. (s.e.) }\end{array}$ & $\begin{array}{l}\text { Postmodernism } \\
\text { Est. (s.e.) }\end{array}$ \\
\hline$\overline{A L P}$ & $4.90(0.53)$ & $-9.54(0.55)$ & $1.18(0.69)$ \\
\hline Nat & $1.98(0.99)$ & $-1.19(0.96)$ & $-7.09(1.34)$ \\
\hline Dem & $0.82(0.63)$ & $-6.54(0.60)$ & $4.24(0.81)$ \\
\hline Grn & $-0.55(1.27)$ & $-9.70(1.16)$ & $6.01(1.53)$ \\
\hline ONP & $7.14(0.74)$ & $-6.43(0.75)$ & $-9.98(1.09)$ \\
\hline
\end{tabular}

Table 5: Model C

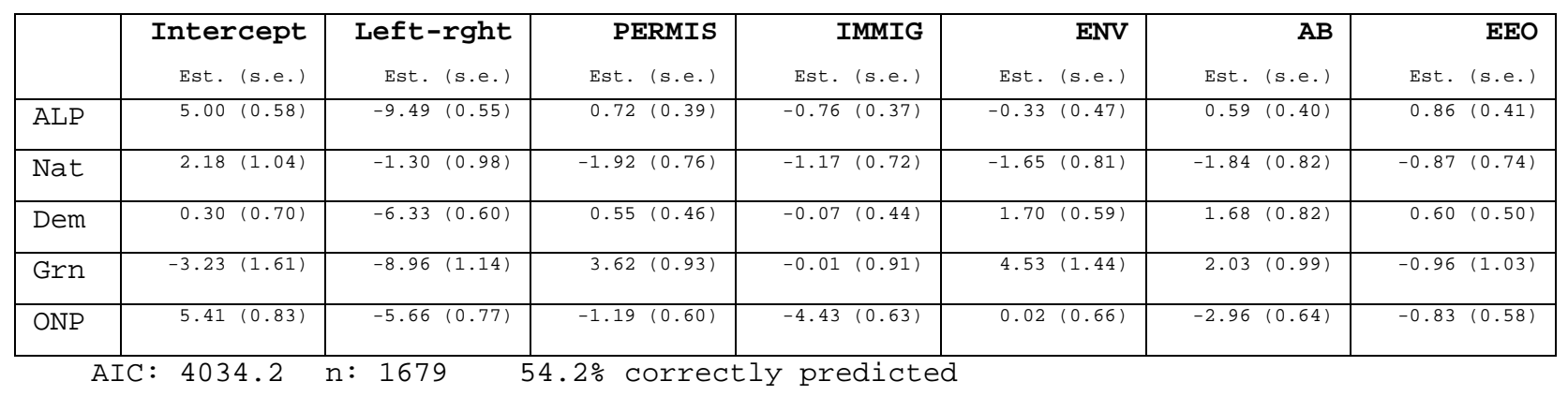

The initial models (A1 and A2) essentially confirm the picture of party support differentiation previously obtained from Figure 3, but they also demonstrate (by comparison of the measures of model fit with those from the null model) that the association between voting and the left-right economic index is overall of considerably more significance than is that with the postmodern index (though this, also, is certainly of importance).

For example, including only the left-right index (model A1) reduces AIC ${ }^{8}$ by 562, whereas including only the postmodern attitudes index (model A2) reduces AIC by only about half as much (294). However, both dimensions are important: including both (model B) reduces AIC by a total of 761 from the null model. The coefficient estimates also clearly show that the left-right economic dimension continues to be primary for differentiating the ALP and Liberal parties from each other. 
Charnock, David and Ellis, Peter. (2004). Postmaterialism and Postmodernization in Australian electoral politics, Electoral Studies, 23(1):45-72.

By way of comparison, a model that included only postmaterialism as an explanatory variable resulted in a reduction in AIC of only 14 over the null model, thus demonstrating that the broader postmodern attitudes index is far superior.

Separating the postmodern index into its five sub-indices (model C) does enhance the model compared to model B, although the extra improvement in model fit is overall relatively small. There is an extra reduction in AIC of 43 compared to the single postmodern attitudes index, indicating that the addition of the single, combined postmodern index captures most of the improvement by itself. Nevertheless, there are other detailed differences between parties that are apparent when the five sub-indices are included and some of these are of considerable interest because they enable a finergrained picture to be obtained ${ }^{9}$. For example,

- Although there was a general tendency for being more postmodern to increase the chances of voting ALP compared to Liberal, the opposite was the case for attitudes towards immigrants when the other attitudes are controlled for. As observed in Charnock (1997a), this creates something of a strategic dilemma for the ALP, because migrants (Asian, in particular) give them disproportionate support. The resulting balancing act that is required might well prove impossible to sustain without losing some voters to ONP.

- National voters can be distinguished in a detailed manner from their Liberal coalition partners, with statistically significant evidence that more conservative views with regard to permissiveness, environmental and aboriginal issues increase the chances of voting National. Attitudes on left-right, migrant and EEO issues tend to have a similar association but the differences are not statistically significant.

- Although being more postmodern has an overall tendency to increase the chances of voting Australian Democrats rather than Liberal, at the level of the separate sub-indices there are significant associations only for environmental and 
Charnock, David and Ellis, Peter. (2004). Postmaterialism and Postmodernization in Australian electoral politics, Electoral Studies, 23(1):45-72.

aboriginal issues. Compared to the ALP, being economically more right-wing and more supportive of environmental issues also significantly increase the chances of voting Democrat.

- Being culturally more permissive increases the chances of voting Green (compared to Liberal) by a significantly greater amount than is the case for any of the other parties. Contrary to expectations from the visual impression in Figure 3, Left-Right economic attitudes do not significantly differentiate between voting for the Greens and the ALP once postmodern issues are controlled for.

- Compared to voting Liberal or National, being more economically left-wing significantly increases the chances of voting for the One Nation Party, but has the opposite effect on the chances of voting for ONP compared to voting for the Greens or the ALP.

In descending order of size, less postmodern attitudes towards immigration, aboriginal and permissiveness issues significantly increase the chances of voting for ONP compared to Liberal. The same is also the case for voting ONP compared with voting ALP, with the addition of EEO attitudes as well. In addition to the left-right difference noted above, the main differentiating factor in voting ONP rather than National is a much stronger association with more negative attitudes towards immigrants.

Whether focusing on the separate sub-indices or on the combined index, a major conclusion from these models is that a postmodern political dimension is of importance in helping understand Senate vote. It reveals strong and obvious differences between the minor parties (Table 4, Model B). Decomposing the postmodern political dimension into five sub-components allows an even finer characterization, with a picture emerging that distinguishes between even closely aligned parties such as the Liberals and Nationals.

It is true that not all of these 5 sub-components are equally important in this respect with, for example, the EEO index having only one statistically significant coefficient and none 
Charnock, David and Ellis, Peter. (2004). Postmaterialism and Postmodernization in Australian electoral politics, Electoral Studies, 23(1):45-72.

having more than the three each of the environmental and aboriginal indices. This raises the possibility that a more parsimonious model might be almost as good. However, although we explored many other models with different combinations of these indices, we found that other sub-components were all necessary (as indicated by AIC). For example, one (which might be suggested by Jackman's (1998) work as well as the patterns of significant coefficients) that included the aboriginal and environmental attitudes indices plus the left-right index had an AIC of 4113.9, making it noticeably inferior to model C (or model B) ${ }^{10}$.

\section{Alternative approach to modelling attitudes and vote}

Instead of modelling how Senate vote depends on the attitudes measured by the various indices, we could consider a reverse model where the response vector consists of the attitudes on the various scales (we use the same ones as in model C in the text), and vote is instead the explanatory variable in the model. For descriptive purposes, this approach has the advantage of countering possible criticisms of the specification of our models of vote ${ }^{11}$.

Using seemingly unrelated regression (SUR) shows a statistically significant overall relationship between senate vote and score on each index. In table 6 below, the position of each party shows how their score, on average, differs from that of the Liberal party, chosen as a reference point.

Table 6: Attitudinal locations of Senate voters for different parties

\begin{tabular}{|r|r|r|r|r|r|r|}
\hline & Left-Right & PERMIS & IMMIG & ENV & AB & EEO \\
\hline Reference (Lib) & 0.6724 & 0.3618 & 0.4430 & 0.7554 & 0.4018 & 0.6034 \\
$\boldsymbol{s} \boldsymbol{e}$ & 0.0063 & 0.0076 & 0.0087 & 0.0065 & 0.0083 & 0.0079 \\
\hline ALP & -0.2096 & 0.0451 & 0.0114 & 0.0370 & 0.0868 & 0.0669 \\
$\boldsymbol{s} \boldsymbol{}$ & 0.0088 & 0.0105 & 0.0121 & 0.0090 & 0.0115 & 0.0110 \\
\hline Nat & 0.0000 & -0.0564 & -0.0711 & -0.0663 & -0.0886 & -0.0739 \\
$\boldsymbol{s} \boldsymbol{}$ & 0.0197 & 0.0235 & 0.0270 & 0.0201 & 0.0258 & 0.0247 \\
\hline Dem & -0.1560 & 0.0324 & 0.0436 & 0.0709 & 0.1227 & 0.0814 \\
$\boldsymbol{s e}$ & 0.0114 & 0.0136 & 0.0156 & 0.0117 & 0.0149 & 0.0143 \\
\hline Grn & -0.2562 & 0.1602 & 0.0745 & 0.1298 & 0.1761 & 0.0834 \\
$\boldsymbol{s e}$ & 0.0239 & 0.0286 & 0.0329 & 0.0245 & 0.0314 & 0.0300 \\
\hline ONP & -0.1021 & -0.0096 & -0.2050 & -0.0049 & -0.1325 & -0.0768
\end{tabular}


Charnock, David and Ellis, Peter. (2004). Postmaterialism and Postmodernization in Australian electoral politics, Electoral Studies, 23(1):45-72.

\begin{tabular}{|l|l|l|l|l|l|l|} 
se & 0.0149 & 0.0177 & 0.0204 & 0.0152 & 0.0195 & 0.0186 \\
\hline
\end{tabular}

For the most part, this table shows similar features to those seen in the multinomial logistic model C. There are a few differences that result from the differing logic of the two approaches: whereas the coefficients in the multinomial model measure the impact on voting of the attitudes measured by each index when the other indices are controlled for, no such controls occur in the reverse model estimated by SUR.

The two most significant differences relate to ALP voters and the IMMIG index and Green voters and the EEO index. In the case of the former, whereas the multinomial model showed that having more postmodern views on immigrants significantly reduced the chances of voting ALP rather than Liberal (once other attitudes were controlled for), the SUR modelling shows no significant difference between ALP and Liberal voters in attitudes towards immigrants. In the case of the latter, while the multinomial model showed (not statistically significant, however) that having more postmodern views on EEO tended to reduce the chances of voting Green rather than Liberal (once other attitudes were controlled for), the SUR modelling shows Green voters to have significantly more postmodern views on EEO than Liberal voters.

In both instances, it is the effect of controlling for the other attitudes that makes the difference: for example, although Green voters overall are more postmodern on EEO than Liberal voters, the extent of this is smaller than would be expected on the basis of their other attitudes.

We prefer to model vote as the dependent variable, but the fact that the features in the two approaches are mainly similar provides additional reassurance that our picture of the impact on the party system of the relationship between postmodern attitudes and vote is robust. 
Charnock, David and Ellis, Peter. (2004). Postmaterialism and Postmodernization in Australian electoral politics, Electoral Studies, 23(1):45-72.

\section{Attitudinal consistency, Distances between parties and Strategic implications}

From a strategic point of view, although the picture we have been able to draw up to this point is certainly very useful for differentiating between the parties, it is essentially based on average attitudinal positions. Another interesting and practically important issue is to examine how much attitudinal variation is present among the voters for each party, and how large are the average distances between the parties’ voters. To the extent that the attitudes being studied here are ones that have an impact on voting behaviour, we can use this information as a guide to how much scope there is for parties to attract voters from (or lose voters to) other parties. It will also give us a rather more precise indication of what we might describe as parties with the most "closely ideologically aligned" supporters.

Since our multinomial logistic modelling has shown that using the five separate postmodern sub-indices (model C) improves model fit by a relatively small amount compared to the model (B) with the left-right economic attitudes index and the combined postmodern attitudes index, we reduce complexity by restricting ourselves to examining the two-dimensional space formed by these last two indices. This also has the advantage of allowing us to make visual comparisons.

The inner and outer contour lines in Figure 4 below enclose 50\% and 90\% respectively of the estimated population voting for each party ${ }^{12}$. We have inserted the axes around a central point $(0.5,0.5)$ in order to more readily make visual distinctions between left- and right-wing voters, and between more or less postmodern voters.

It is immediately obvious that there is a considerable degree of crossover between the supporters of the various parties, despite the degree of separation between the centres of density for each party previously indicated in Figure 3. This is, of course, important because it gives rise to potential vote switching between parties. 


\section{Figure 4}

\section{Intra-party Variations in Postmodern political and Left-Right economic Position of Senate voters 1998}

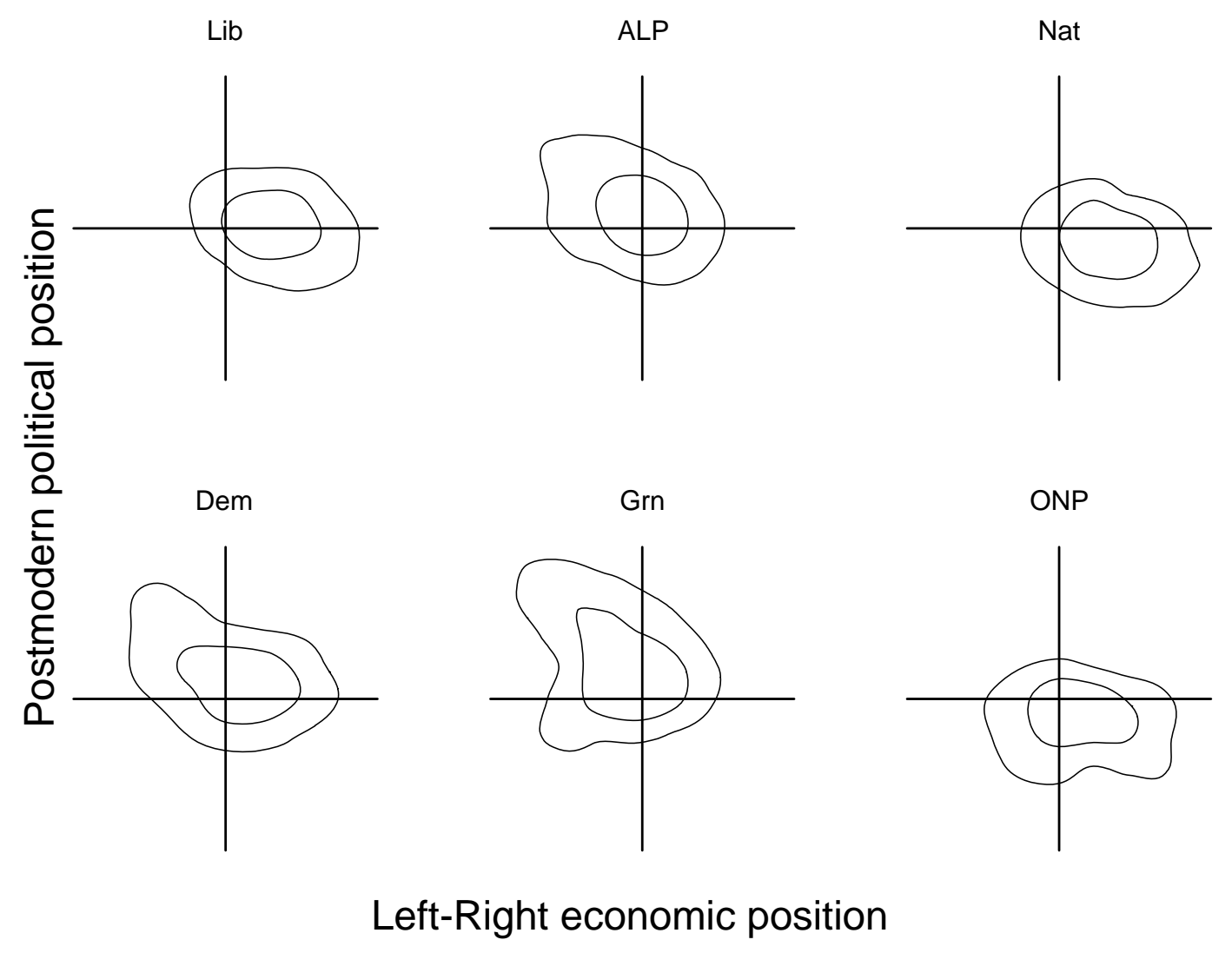

Note: inner lines enclose $50 \%$ and outer lines $90 \%$ of the estimated voting population for each party

The general pattern is for the central $50 \%$ of voters for all parties to have quite coherent attitudes, but for this to be less so for remaining voters (much less so for Democrats and Greens voters especially). The most internally consistent attitudes were held by voters for the two coalition parties, closely followed by ONP and the ALP, while voters for the Greens and Democrats clearly did not have attitudes that were as consistent as those of other parties. One especially interesting finding here is that the attitudes of ONP voters were much more consistent than the Greens and Democrats and were, in fact, a little more consistent than those of ALP voters. Again, to the extent that these attitudes are 
Charnock, David and Ellis, Peter. (2004). Postmaterialism and Postmodernization in Australian electoral politics, Electoral Studies, 23(1):45-72.

significant in determining voting behaviour, the position of the ALP seems slightly weaker than the Liberals, though the extent of the intra-party variations for most of the parties is fairly large.

It is possible to calculate the distance between any two individuals in this twodimensional (left-right economic and postmodern attitudes) space, and we can use this as the basis for giving another measure of attitudinal consistency within parties and also of distances between parties. Figure 5 shows the mean distances between individuals voting for one party and individuals voting for another party. To make interpretation simpler, these mean distances are standardised to make the ALP-ALP within-group mean distance equal to one. The horizontal lines in Figure 5 show 95\% confidence intervals that give some idea of the statistical uncertainty of any interpretation.

\section{Figure 5}

\section{Mean distance between individuals in different Senate vote groupings 1998}

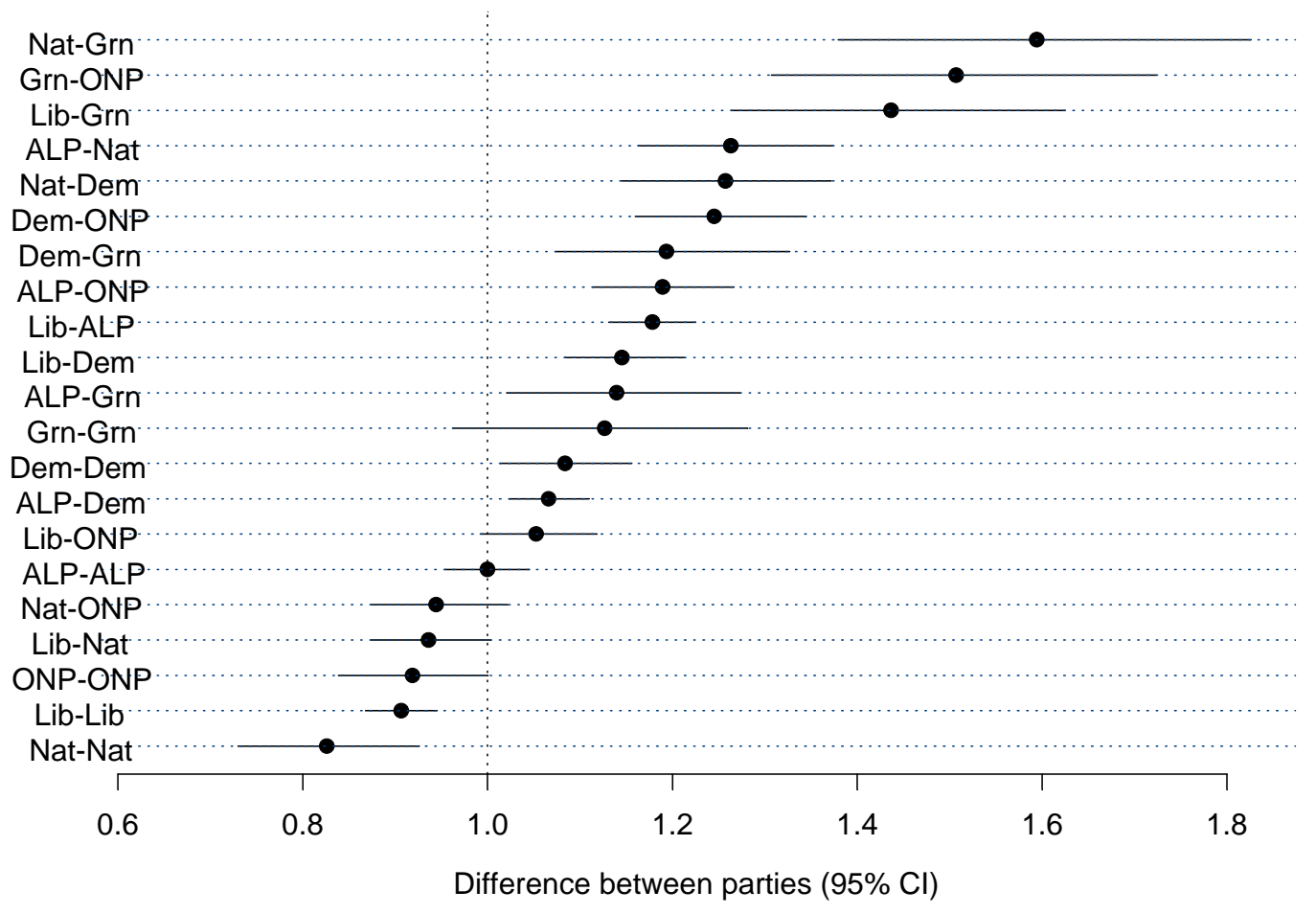

Note: the central dots are the estimated mean distances between groupings and the horizontal lines show 95\% confidence intervals for the mean distances (based on 2000 bootstrap repetitions) 
Charnock, David and Ellis, Peter. (2004). Postmaterialism and Postmodernization in Australian electoral politics, Electoral Studies, 23(1):45-72.

Comparison of the intra-party average distances shown in Figure 5 confirms the visual impression obtained earlier from Figure 4 that voters for the more right-wing parties (Liberals, Nationals and ONP) are more ideologically coherent than those voting for the other parties (ALP, Democrats, Greens). Presumably, this must help to provide a more secure core of voters for these parties.

A number of other interesting features can also found in Figure 5. The attitudes of Liberal and National voters are the closest of any inter-party pair (a good foundation for a Coalition!), but the difference is not significantly different from that between ONP and National voters. The ALP-Democrats difference is the smallest of all the more left-wing party comparisons, but is not significantly different from the ALP-Green difference. The biggest distances all involve economically right-wing parties and the Greens (Greens-ONP, Greens-Nationals and Greens-Liberal): an interesting indicator that in this ideological space, it is the Green Party and not the ONP that is the real outsider in Australian politics. Green voters are both the most left-wing and the most postmodern; on the other hand, while ONP voters are the least postmodern, they are relatively central on left-right economic issues.

Naturally, one important practical question is that of which party may find its support base eroded by ONP. Charnock (1999) found that on socio-demographic variables, the ONP support base had many similarities to that of the ALP. However, on the basis of the attitudes studied here, what we can see from the position of ONP is that it is placed to potentially attract voters from both the ALP and the coalition: from the Nationals and Liberals, some less postmodern voters who are more centrally located on economic issues, and also some of the less postmodern and more right-wing ALP voters (of which Figure 4 shows there are quite a lot).

\section{Conclusion}


Charnock, David and Ellis, Peter. (2004). Postmaterialism and Postmodernization in Australian electoral politics, Electoral Studies, 23(1):45-72.

The analyses presented here clearly show that a single left-right economic dimension is insufficient to adequately describe voter differences between Australian parties, although it remains the principal aspect dividing ALP from Liberal party voters. An additional dimension is required in order to properly understand the location of other parties including ONP. Since they have had most exposure and the longest history of empirical investigation internationally, we began by considering whether the ideas about social and political change suggested in Inglehart's notions based on postmaterialism would be enough to understand the nature of this extra dimension. It immediately became clear that the four-item postmaterialism measure available in the AES98 was inadequate because of its quite counterintuitive placement of ONP as one of the most postmaterialist of parties, when all other evidence suggests differently. This finding provides support for other recent research that suggests this measure has significant flaws.

We therefore developed a much broader index of postmodern attitudes (formed from 23 survey items) and investigated its usefulness. We discovered that a two-dimensional space with traditional left-right economic attitudes on one axis and postmodern attitudes on the other (somewhat in the style of Inglehart's more recent writing) was adequate as a broad brush measure to describe differences between Australian political parties at the 1998 federal election. We do, however, note that the left-right dimension remains of more overall importance, largely because it is this dimension that mainly serves to differentiate voters for the two major parties (the ALP and the Liberals) ${ }^{13}$.

The positioning of political parties in this two-dimensional space, as judged by the attitudes of their voters in the Senate, is reasonably close to that predicted by Inglehart's recent theories, except for the more extreme left-wing position of the Greens on the traditional left-right economic axis. However, it fits even better with Kitschelt's description of the structure of European party competition.

Although adding the single combined postmodern index was, by itself, enough to capture most of the gain in model fit, we did also find that breaking it down into its subcomponents offered something of value. At the individual level, differing attitudes to immigration, Aborigines, social permissiveness and the environment are all statistically 
Charnock, David and Ellis, Peter. (2004). Postmaterialism and Postmodernization in Australian electoral politics, Electoral Studies, 23(1):45-72.

significant predictors of Senate vote. Their main use is in giving a more detailed picture of differentiation, particularly between the minor parties. Multinomial logistic models show that these separate components are useful predictors in some cases (such as immigration for One Nation and the environment for the Greens and Democrats) but that, in contradiction to what we might have concluded from the simpler two-dimensional depiction of attitudinal space, low xenophobia is not a good predictor of Greens voting nor low environmental concern a good predictor of ONP voting, when compared to a Liberal party baseline. Thus even a two-dimensional picture of Australian politics, while a very useful broad brush and a big improvement on a narrower single-dimensional focus on left-right economic ideology, can be improved on.

Another important practical aspect of our research was to explore the internal coherence of the attitudes held by the voters for the various parties, and to investigate the extent of overlaps between parties, because such overlaps provide ready scope for switching of voters between parties. We found that the greatest degree of internal coherence was among the three more right-wing parties, including ONP, thus giving them a potentially firmer base of support. In studying the distances between supporters of different parties we were able to make some interesting observations, including an intuitive clustering of voters into two camps: one more left-wing and postmodern (ALP, Democrats and Greens), and the other more right-wing and less postmodern (Liberal, National and ONP).

Despite this, however, there is a good deal of intra-party variation in attitudes and, because of this spread of attitudes and the degree of overlap we found, ONP are apparently well positioned in this two-dimensional space to gain votes both from the coalition parties and from the ALP. The strategic possibilities within the Australian party system have expanded as a result. The Greens, in contrast, are located as the most extreme party on both dimensions, seemingly offering them less scope.

In a comparative context, Australia is quite interesting because, unlike many of the European social democratic parties, the ALP was very electorally successful in the 1980s and early 1990s, winning five consecutive federal elections and being in government 
Charnock, David and Ellis, Peter. (2004). Postmaterialism and Postmodernization in Australian electoral politics, Electoral Studies, 23(1):45-72.

from 1983 to 1996. This was achieved at the same time as it introduced some quite profound changes in its economic policies, including the privatization of significant components of the public sector. One aspect of the explanation for its success is undoubtedly its adaptation to the changes associated with the postmodern dimension studied here. At the same time, structural aspects of the electoral system (particularly compulsory voting and voter registration, and the use of full preferential voting systems) helped to reduce the slippage of less postmodern voters away from the party. It now appears, however, that the emergence of ONP might well have altered this situation, though the organizational stability of that party is still in question. 
Charnock, David and Ellis, Peter. (2004). Postmaterialism and Postmodernization in Australian electoral politics, Electoral Studies, 23(1):45-72.

\section{Appendix}

\section{Postmaterialism indices}

One of Inglehart's two materialism-postmaterialism indices (used in the earliest research) is based on a four-item battery; the other index is based on a twelve-item battery, which consists of 3 separate ranking exercises, the second of which is effectively the four-item battery (Inglehart 1997: 355). Each of the ranking exercises is prefaced with the question "There is a lot of talk these days about what the aims of this country should be for the next ten years. On this card are listed some of the goals which different people would give top priority. Would you please say which one of these you, yourself, consider the most important? And which would be the next most important?”

The options for the first question are: "maintaining a high level of economic growth; making sure that this country has strong defence forces; seeing that people have more to say about how things are done at their jobs and in their communities; trying to make our cities and countryside more beautiful”.

The options for the second question (which is effectively the four-item battery) are: "maintaining order in the nation; giving people more say in important government decisions; fighting rising prices; protecting freedom of speech".

The options in the third question are: "having a stable economy; progress towards a less impersonal and more humane society; the fight against crime; progress towards a society in which ideas count more than money".

From the twelve-item battery, a postmaterialism index is created from the number of the six options chosen which are postmaterialist rather than materialist - the distinction should be fairly obvious to the reader, except in the case of "trying to make our cities and countryside more beautiful”, which Inglehart does not include on the side of postmaterialism because of (for him, disappointing, since it was designed to measure an element of postmaterialism) low correlation with the other postmaterialist options, apparently tapping instead into fears about urban crime. Consequently, Inglehart does 
Charnock, David and Ellis, Peter. (2004). Postmaterialism and Postmodernization in Australian electoral politics, Electoral Studies, 23(1):45-72.

not include this item in his postmaterialist index, which thus ranges from zero (completely materialist) to five (chose all the available postmaterialist options).

\section{Factor Analysis}

In the text, we used equal weighting of (scaled) variables to create an index for each of the five components we had identified from Inglehart's ideas on postmodernization. This is justified by exploratory factor analysis we carried out of the proposed component variables in conjunction with Inglehart's postmaterialism index built from the 4 question battery used in the 1998 AES.

We followed the approach of Jackman (1998) in basing our analysis on polychoric correlations, which are better estimates of the true relationship between the assumed latent variables that manifest themselves in the ordinal responses to the survey items. Exploratory factor analysis (particularly determining the necessary number of dimensions to summarise data) is necessarily an art rather than a science, but examination of a scree plot (which shows the diminishing explanatory power of each additional principal component) suggests a 5 dimensional solution, with these dimensions together explaining 58.3 per cent of the total variance. This conclusion is supported by that from another widely used criterion (Kaiser’s) that suggests, when using a correlation matrix, keeping those principal components with an eigenvalue greater than 1 .

We experimented with rotations of the 4 and 5 factor solutions. In each case, after rotation (rotation method having no substantive impact on the interpretation below) each factor was strongly associated with the particular questions that made up one of our indices in the text (EEO and IMMIG being the indices combined into one in the fourfactor solution). The table below shows the largest loadings (all those over 0.20 ) from the five-factor varimax-rotated solution. 
Charnock, David and Ellis, Peter. (2004). Postmaterialism and Postmodernization in Australian electoral politics, Electoral Studies, 23(1):45-72.

\section{Five-factor solution loadings (after varimax rotation)}

\begin{tabular}{|l|ccccc|}
\hline \multicolumn{1}{|c|}{ AES98 variable } & Factor 1 & Factor 2 & Factor 3 & Factor 4 & Factor 5 \\
\hline E2NUDSEX & & & -0.43 & & \\
E3 & & & -0.51 & & \\
E4 & & & -0.46 & \\
E6MARIJ & & & -0.40 & & \\
E17P5 & & & -0.34 & & \\
F6 & 0.45 & & & & \\
F7P1 & 0.47 & & & & \\
F7P3 & 0.48 & & & & \\
F5P11 & 0.32 & & & & \\
E14PRESN & & 0.47 & & -0.34 & \\
E14SPEND & & 0.51 & & -0.36 & \\
E14POLLT & & 0.52 & & -0.42 & \\
E15ENVIR & & 0.45 & & -0.50 & \\
E2ABLAND & & & & -0.38 \\
E2ABOR & & & & -0.38 \\
G14P7 & & & & -0.53 \\
G14P8 & & & & -0.53 \\
G14P9 & & & & \\
E2EQUOP & & & & \\
E6OPP & & & & \\
E17P2 & & & & \\
E17P3 & & & & \\
E17P4 & & & & \\
Post-materialism & & & & & \\
\hline
\end{tabular}

Note: Only loadings over 0.20 are shown. AES98 variable codes were reordered where necessary to make higher values correspond to postmodern attitudes.

As can be seen, postmaterialism (as derived from the four item battery) is unimportant in the above factor analysis (its highest loading is actually only 0.12) and, indeed, has no polychoric correlation coefficient exceeding 0.2 with any of the other variables.

Also, these factor loadings are reasonably close to simple averages for the items in the corresponding sub-indices (when the original variables are on the same scale) and, not surprisingly, when we repeated the analyses reported in the text using indices created from the factor scores we obtained almost identical conclusions. We decided to use the approach in the text for simplicity and ease of interpretation. 
Charnock, David and Ellis, Peter. (2004). Postmaterialism and Postmodernization in Australian electoral politics, Electoral Studies, 23(1):45-72.

\section{Odds ratio changes presentation of Model C}

An alternative presentation of the results of multinomial logistic regression models is based on odds ratios. Since this involves comparisons of all pairs of parties, it generates large sets of numbers and so we only give such a presentation for our most complex model (C).

The following table shows, for each pair of parties, the proportional increase in the voting odds for an increase of 0.1 in the indicated index. Two examples illustrate how the table can be interpreted: first, moving 0.1 along the economic index to the right will increase the odds of voting Liberal rather than Labor just more than two and one half-fold (2.58 times) over what they would have been otherwise; second, moving 0.1 in the postmodern direction of the permissiveness index will reduce the odds of voting Liberal rather than Green to just over two-thirds ( 0.70 times) what they would have been otherwise.

\begin{tabular}{|lrrrrrr|}
\hline & Left-right & PERMIS & IMMIG & ENV & AB & EEO \\
\hline Lib/ALP & 2.58 & 0.93 & 1.08 & 1.03 & 0.94 & 0.92 \\
Lib/Nat & 1.14 & 1.21 & 1.12 & 1.18 & 1.20 & 1.09 \\
Lib/Dem & 1.88 & 0.95 & 1.01 & 0.84 & 0.85 & 0.94 \\
Lib/Grn & 2.45 & 0.70 & 1.00 & 0.64 & 0.82 & 1.10 \\
Lib/ONP & 1.76 & 1.13 & 1.56 & 1.00 & 1.35 & 1.09 \\
ALP/Nat & 0.44 & 1.30 & 1.04 & 1.14 & 1.27 & 1.19 \\
ALPIDem & 0.73 & 1.02 & 0.93 & 0.82 & 0.90 & 1.03 \\
ALPIGrn & 0.95 & 0.75 & 0.93 & 0.62 & 0.87 & 1.20 \\
ALP/ONP & 0.68 & 1.21 & 1.44 & 0.97 & 1.43 & 1.18 \\
Nat/Dem & 1.65 & 0.78 & 0.90 & 0.72 & 0.70 & 0.86 \\
Nat/Grn & 2.15 & 0.57 & 0.89 & 0.54 & 0.68 & 1.01 \\
Nat/ONP & 1.55 & 0.93 & 1.39 & 0.85 & 1.12 & 1.00 \\
Dem/Grn & 1.30 & 0.74 & 0.99 & 0.75 & 0.97 & 1.17 \\
Dem/ONP & 0.94 & 1.19 & 1.55 & 1.18 & 1.59 & 1.15 \\
Grn/ONP & 0.72 & 1.62 & 1.56 & 1.57 & 1.65 & 0.99 \\
\hline
\end{tabular}


Charnock, David and Ellis, Peter. (2004). Postmaterialism and Postmodernization in Australian electoral politics, Electoral Studies, 23(1):45-72.

\section{References}

Abbott, T. ed. (1998). Two Nations: The Causes and Effects of the Rise of the One Nation Party in Australia. Melbourne: Bookman.

Bean, C., D. Gow and I. McAllister (1999). Australian Election Study 1998: User's Guide for the machine-readable data file. Canberra: Social Science Data Archives, Australian National University.

Bean, C. and E. Papadakis (1994). "Polarized priorities or flexible alternatives?

Dimensionality in Inglehart's Materialism-Postmaterialism Scale." International Journal of Public Opinion Research 6 (3): 264-88.

Blount, S. (1998). "Postmaterialism and the Vote for the Senate in Australia." Australian Journal of Political Science 33(3): 441-449.

Charnock, D. (2001). "National Identity, Partisanship and Populist Protest as Factors in the 1999 Australian Republic Referendum." Australian Journal of Political Science 36: 271-291.

Charnock, D. (1999). "Voting at the 1998 Australian Federal Election: Studying major and minor parties simultaneously." In Proceedings of the 1999 Conference of the Australasian Political Studies Association Sydney: Department of Government, University of Sydney / APSA, vol. 1 pp 91-99.

Charnock, D. (1997b). "Class and Voting in the 1996 Australian Federal Election." Electoral Studies 16: 281-300.

Charnock, D. (1997a). "Spatial Variations, Contextual and Social Structural Influences on Voting for the ALP at the 1996 Federal Election: Conclusions from Multilevel Analyses." Australian Journal of Political Science 32: 237-254.

Charnock, D. (1996). "Question-Wording Effects on the Measurement of Nonpartisanship: Evidence from Australia." Electoral Studies 15: 263-268.

Clarke, H. D., A. Kornberg, C. McIntyre, P. Bauer-Kaase and M. Kaase (1999). “The Effect of Economic Priorities on the Measurement of Value Change: New Experimental Evidence.” American Political Science Review 93(3): 637-647.

Davis, D. W. and C. Davenport (1999). “Assessing the Validity of the Postmaterialism Index.” American Political Science Review 93(3): 649-664. 
Charnock, David and Ellis, Peter. (2004). Postmaterialism and Postmodernization in Australian electoral politics, Electoral Studies, 23(1):45-72.

Denemark, D. and S. Bowler (2002). "Minor parties and protest votes in Australia and New Zealand: locating populist politics." Electoral Studies 21: 47-67.

Gibbins, J.R. and Bo Reimer (1999). The Politics of Postmodernity. London: Sage.

Gibson, R., I. McAllister and T. Swenson (2001). "The Politics of Race and Immigration in Australia: One Nation Voting in the 1998 Election", Canberra: Research School of Social Sciences, The Australian National University.

Goot, M. and I. Watson (2001). "One Nation's Electoral Support: Where does it come from, What makes it different and How does it fit?" Australian Journal of Politics and History 47: 159-191.

Gow, D. J. (1990). "Economic voting and postmaterialist values." In C. Bean, I. McAllister and J. Warhurst (eds). The Greening of Australian Politics: the 1990 Federal Election. Melbourne: Longman Cheshire: chapter 4, pp 54-71.

Hellevik, O. (1993). "Postmaterialism as a Dimension of Cultural Change." International Journal of Public Opinion Research 5: 211-233.

Inglehart, R. (1997). Modernization and Postmodernization: Cultural, Economic, and Political Change in 43 Societies. Princeton, New Jersey, Princeton University Press.

Inglehart, R. (1990). Culture Shift in Advanced Industrial Society. Princeton, New Jersey, Princeton University Press.

Inglehart, R. (1977). The Silent Revolution: Changing Values and Political Styles. Princeton, New Jersey, Princeton University Press.

Inglehart, R. and P. R. Abramson (1999). “Measuring Postmaterialism.” American Political Science Review 93(3): 665-678.

Jackman, S. (1998). "Pauline Hanson, the mainstream, and political elites: The place of race in Australian political ideology.” Australian Journal of Political Science 33(2): 167-186.

Johnston, R.J. and C. Pattie (2000). "Inconsistent Individual Attitudes within Consistent Attitudinal Structures." British Journal of Political Science 30: 361-374.

Kitschelt, H. (1995). The Radical Right in Western Europe: A Comparative Analysis. Ann Arbor, University of Michigan Press. 
Charnock, David and Ellis, Peter. (2004). Postmaterialism and Postmodernization in Australian electoral politics, Electoral Studies, 23(1):45-72.

Kitschelt, H. (1994). The Transformation of European Social Democracy. Cambridge: Cambridge University Press.

Knutsen, O. (1995). "Party Choice." In J.W. van Deth and E. Scarbrough (eds.), The Impact of Values. Oxford, Oxford University Press: 461-491.

Long, J.S. (1997). Regression Models for Categorical and Limited Dependent Variables. Thousand Oaks, CA: Sage.

McAllister, I. (1997). "Political Behaviour." In D. Woodward, A. Parkin and J. Summers (eds) Government, Politics, Power and Policy in Australia 6th ed., Melbourne: Longman pp 240-268.

McAllister, I. (1992). Political Behaviour: Citizens, Parties and Elites in Australia. Melbourne: Longman Cheshire.

McAllister, I. and C. Bean (2000). "The electoral politics of economic reform in Australia: the 1998 election.” Australian Journal of Political Science 35(3): 383399.

McAllister, I., R. Jones, E. Papadakis and D.J. Gow. (1990). Australian Election Study 1990: User's Guide for the machine-readable data file. Canberra: Social Science Data Archives, Australian National University.

Marks, G.N. and C. Bean (1992). "Sources of Electoral Support for Minor Parties: The Case of the Australian Democrats." Electoral Studies 11: 311-333.

Rokeach, M. (1973). The Nature of Human Values. New York, NY: Free Press.

Venables, W. and B. Ripley (1999). Modern Applied Statistics with S-Plus 3rd ed., New York, Springer.

Warwick, P. V. (1998). "Disputed cause, disputed effect: the postmaterialist thesis reexamined.” Public Opinion Quarterly 62(4): 583-609

Weakliem, D. L. and M. Western (1999). "Class voting, social change, and the left in Australia, 1943-96.” British Journal of Sociology 50(4): 609-630.

Western, M. and B. Tranter (2001). "Postmaterialist and Economic voting in Australia, 1990-1998." Australian Journal of Political Science 36: 439-458. 
Charnock, David and Ellis, Peter. (2004). Postmaterialism and Postmodernization in Australian electoral politics, Electoral Studies, 23(1):45-72.

\section{Notes}

1. For example, more than 40 parties (not counting state branches of the ALP, Liberals and Nationals separately) were officially registered at the 1998 federal election.

2. Computing was done with S-Plus and SPSS. Details are available on request.

3. Although the Liberals and Nationals ran joint tickets in some states, AES respondents in those states were able to (and did) identify themselves as having voted for the separate parties.

We did replicate some analyses using House of Representatives vote and found that many of the main features were similar to those found using Senate vote, though there are differences of detail and, as mentioned, Liberals and Nationals cannot reliably be separately identified.

4. We also tried an alternative approach, involving factor analysis of the 23 items and using the resulting factor scores to create the five indices. This produced results with essentially the same interpretation as those presented here. The factor analysis is described in the appendix.

5. Evidence in support of this is provided by the facts that almost all of the 23 items have significant loadings on the first principal component, and that this component by itself explains 24 per cent of the total variance.

6. Reliability coefficients for the various indices were as follows: Left-Right Economic (0.70); Combined Postmodern (0.80); PERMIS (0.52); IMMIG (0.76); ENV (0.80); AB (0.82); EEO (0.71). From the items available in the AES we were unable to find a more satisfactory scale to measure cultural permissiveness than PERMIS.

7. We thank one of the journal's referees for suggesting we investigate these models. 
Charnock, David and Ellis, Peter. (2004). Postmaterialism and Postmodernization in Australian electoral politics, Electoral Studies, 23(1):45-72.

8. AIC, "Akaike's Information Criterion" is an indicator of goodness of fit that is widely used to compare rival models if they differ only in the choice of explanatory variables. AIC consists of the model deviance penalised by adding twice the number of parameters in the model.

We also show the percentage of cases whose Senate vote is correctly predicted by each of the models. This measure is not very discriminating in situations like this, where a small number of not widely separated categories (here, voting ALP and Liberal) occur with much greater frequency than other categories. Even in model C, for example, all but 60 cases are predicted to vote either ALP or Liberal.

9. Also see the appendix for an odds ratio-based presentation of the model C results.

10. Another model with AB replaced by IMMIG had an almost identical AIC value of 4111.8

11. We are indebted to one of the journal's reviewers for this observation, and for suggesting this alternative approach.

12. The contour plots are based on bivariate normal kernel density estimates smoothed using locally weighted regression. For the former, see the software associated with Venables and Ripley (1999).

13. This is consistent with the finding in Charnock (1997b) that work-related factors remained important in voting at the 1996 election, despite conventional measures of occupational class showing only limited association with voting. 